UDC 378.048.2: 004.67: 004.942:519.6

\author{
Olesia P. Nechuiviter \\ Doctor of Physical and Mathematical Science, Associate Professor, \\ Head of the Department of Information Computer Technologies and Mathematics \\ Ukrainian Engineering and Pedagogical Academy, Kharkiv, Ukraine \\ ORCID ID 0000-0003-2775-8471 \\ olesia.nechuiviter@gmail.com
}

\title{
APPLICATION OF THE THEORY OF NEW INFORMATION OPERATORS IN CONDUCTING RESEARCH IN THE FIELD OF INFORMATION TECHNOLOGIES
}

\begin{abstract}
Due to the rapid development and implementation of the latest information technologies in many fields of science and technology significant changes have taken place. In particular, new mathematical theories have emerged; they can be effectively used in building and improving existing mathematical models of various phenomena and objects. Mathematical modeling is currently one of the main methods in scientific research of technological, social, economic processes and natural phenomena. No research thesis is complete without the use of mathematical methods and algorithms. In view of this it is important to acquaint young scientists with modern trends in mathematical modeling during their training for $\mathrm{PhD}$ degree, in particular.

The development of information technology has contributed to the emergence of new approaches to obtaining, processing and analyzing information in scientific research. In this way, the theory of new information operators, which is widely used in mathematical modeling, was created.

The analysis of the existing research reveals the need to consider the theoretical basics of new information operators and their application to the numerical integration of several variables functions. The example of the problem of numerical integration of two variables functions shows the way how to create cubature formulas depending on the type of the input information about function. The paper presents new cubature formulas for the approximate calculation of double integrals, in the case when the information is given by the set of traces on lines and values of the function at points. The proposed formulas have high accuracy but use much less input information compared to classical formulas for numerical integration of double integrals. All the results are supported by numerous examples made in the computer mathematics system Mathcad.

The implementation of the developed methodology of using new information operators in scientific research has shown its efficacy during seminars with Master and PhD students.
\end{abstract}

Keywords: ICT; mathematical modeling; new information operators; numerical algorithms; integration of functions of many variables; Mathcad; PhD students.

\section{INTRODUCTION}

Modern experience of many countries shows that the transition to a new development stage is impossible without domestic specialists who have knowledge in the field of advanced science. High technologies cause the emergence of complex engineering, economic, pedagogical, social problems that require additional knowledge, skills, and abilities. Therefore, the education system needs scientific and pedagogical staff whose level of training and competence would meet today's requirements.

Graduate students need to study facts, phenomena and processes, understand the patterns, development features and formation of scientific discoveries. They need to know the methods of scientific research, be acquainted with modern scientific hypotheses and different areas of research in the relevant field of knowledge.

Mathematical modeling is an important part of modern scientific research. It has widely penetrated into various fields of science and technology, which at first glance are far from mathematics. The impetus for the development of mathematical modeling was the emergence of electronic computers that are able to perform arithmetic and logical calculations at high 
speed. The necessity to solve difficult problems prompted scientists to develop mathematical models, identify the basic patterns of the studied phenomena, and create effective numerical algorithms for their solution. In turn, the implementation of these algorithms on computers has led to the creation of new programming languages, operating systems and software support systems, the development of new approaches in programming and information technology. The interconnected process of development of mathematical models, numerical algorithms, programming and creation of complexes of programs for solving these problems, their analysis, storage and output of calculation results served as a basis for new directions in scientific research. One of such directions in mathematical modeling is the theory of new information operators [1]. The new information operators give the possibility to focus on such stages of mathematical modeling as the preparation of initial information in modeling processes and phenomena, the development of algorithms for numerical problem solving, computer programming and direct calculations.

It is natural that scientists in many scientific areas, especially young ones, should be familiar with new theories, inasmuch as they face the need to process the data of the experimental research. The theory of new information operators could encourage scientists in various fields to use new opportunities in mathematical modeling and information technology.

The problem statement. The current stage of the development of many fields of knowledge (astronomy, radiology, computed tomography, holography, radar, etc.) is characterized by the rapid introduction of new digital technologies, algorithms and methods. Scientists are building new or improving already known mathematical models using information technology [2]. Today many problems are being solved in cases when the input information about a function is a set of traces of the function on planes, set of traces of the function on lines or a set of values of the function in the points. It has been proven that different views on data can give new results in digital signal and image processing, in space, computed tomography, seismic tomography and non-destructive testing [3], [4]. By understanding the principles of building new information operators, professionals in other scientific areas may consider a possibility of solving their problems by using other types of data. Important aspects of such a way include a search for a wide-spread problem, which is able to demonstrate the efficacy of using new information operators, as well as the presentation of well-defined algorithms and methods for the above-mentioned issue in modern systems of computer mathematics Mathcad, Wolfram Mathematica.

Analysis of recent studies and publications. Within the framework of the training of $\mathrm{PhD}$ students, much attention is paid to the mathematical modeling in various fields of science and technology. According to the field in which the research is carried out, the degree seekers are supposed to take either the general course "Mathematical Modeling in Research" [5] or "Mathematical Modeling in the Field" [6]. Such attention is paid to mathematical modeling since it is currently considered to be an effective method in scientific research. Information technologies play a special role in mathematical modeling [7], [8].

The rapid development of information technology leads to the creation of innovative mathematical directions, theories, and algorithms. Such innovative areas include the creation of new information operators. The founder of this scientific direction is O.M. Lytvyn Doctor of Physical and Mathematical Sciences, Professor of the Department of Information Computer Technologies of the Ukrainian Engineering Pedagogics Academy. The new information operators include operators of interlineation, interflatation, interstripation, and others [9] - [11]. They have effectively proven themselves in mathematical modeling in various scientific fields. The main idea in building mathematical models of processes and phenomena is a new look at obtaining and processing experimental data. In particular, mathematical models are being developed where the information about a function can be given by traces on stripes, planes, lines, and points. The developed algorithms have high 
accuracy and use less experimental data to achieve the desired result comparing to the classical methods and algorithms. Along with the development of mathematical theory, the scientific school of O.M. Lytvyn is fruitfully working on the introduction of innovative methods in teaching $\mathrm{PhD}$ students. Algorithms, methods, programs that can be widely used in mathematical modeling of various processes, are covered in the following textbooks [12] [15]. These techniques can assist young scientists in obtaining new scientific results.

Today scientists are interested in the problems of multidimensional numerical integration. Modern methods are studied and can be used in solving engineering [16], or economic problems [17]. The approximate calculation of integrals from highly oscillating functions occupies a special place in the numerical calculation of functions of several variables. Such integrals are widely used in digital signal and image processing, astronomy, physics and in optic research. The paper [18] focuses on investigating the special features of certain typical high-dimensional finance problems, namely, option pricing and bond valuation. It should be noted that all the above-mentioned classical and more recent methods of multidimensional numerical integration use nodes as input information.

The article's goal. The aim of the article is to highlight, using the example of the problem of numerical integration of functions of two variables, modern approaches in mathematical modeling and information technologies, in particular using new information operators, which allow young scientists to effectively conduct research in terms of obtaining data for research, processing, analysis and numerical implementation on computers using modern technologies.

\section{THEORETICAL FUNDAMENTALS OF RESEARCH}

\subsection{Stages of the modeling process}

In different fields of knowledge, the stages of the modeling process acquire their specific features. But in all cases, we can identify several stages inherent in one way or another in the modeling process in any field [19], [20].

1. Problem statement and its qualitative analysis. The main thing is to clearly formulate the essence of the problem, the accepted assumptions and the questions that need to be answered.

2. Construction of a mathematical model. This is the stage of formalization of the problem, expression in the form of specific mathematical dependencies and relations.

3. Mathematical analysis of the model. The purpose of this stage is to clarify the general properties of the model. Analytical study of the model clarifies such issues as, for example, the uniqueness of solutions, which variables can be included in the solution, what type of relations will be between them, within what limits and depending on what initial conditions they change, etc.

Models of complex objects are difficult to subject to analytical study. In cases where analytical methods can not determine the general properties of the model, one moves to numerical research methods.

4. Preparation of input information. Depending on the nature of the processes, there are also types of mathematical modeling, for example, deterministic, stochastic, static, and dynamic. According to the type of modeling in the process of information preparation, the methods of probability theory and mathematical statistics, one- and multidimensional theory of interpolation and approximation are widely used.

Along with the problems of multidimensional interpolation in the construction of mathematical models of various processes, the theory of new information operators has been used for many decades. 
New information operators include operators of interlineation, interflatation, interstripation and others. The theory of new information operators has effectively proved itself in many branches of science, in particular, in the mathematical modeling of socioeconomic and natural processes.

Let us focus on planning an experiment for recovery function $f(x, y)$ and let us find a dependence $z=f(x, y)$ that describes some characteristic of the process. To do so, of course, the values $x_{1}, \ldots, x_{m}$ of the parameter $x$ are fixed and for them there are functions $\psi_{k}(y)=f\left(x_{k}, y\right), \quad k=\overline{1, m}$ (functions $\psi_{k}(y)$ can be represented in the form of graphs drawn by a record or can approximate their values at several points $y_{1}<y_{2}<\cdots<y_{n}$ ). Variables $x$ and $y$ can be swapped: fix the value $y_{1}, \ldots, y_{n}$ of the parameter $y$ and find the functions for these values $\varphi_{l}(x)=f\left(x, y_{l}\right), \quad l=\overline{1, n}$.

The obtained information is used to build the desired function $f(x, y)$ in the form of a Lagrange polynomial from variables $x$ and $y$, or in the form of some piecewise polynomial function (spline), which interpolates data on a selected set of nodes $\left(x_{k}, y_{l}\right)$, or in the form of a smoothing spline, whose coefficients are least squares.

It is important to mention that in practice only functions $\psi_{k}(y)$ or only functions $\varphi_{l}(x)$ are often used. The use of interlineation makes it possible to take into account functions $\psi_{k}(y)$ and functions $\varphi_{l}(x)$ at the same time, which, of course, gives a more accurate approximation to the function $f(x, y)$.

In the general case, it is desirable to conduct the experiment so as to find the value of the function $f(x, y)$ (or its traces) not on a series of straight lines parallel to the coordinate axes, but on a series of straight lines (or curves) of a more general position.

5. Numerical solution. This stage includes the development of algorithms for numerical solution of the problem, compiling programs on a computer and direct calculations. Here, various methods of data processing, solutions of various equations, calculation of integrals become relevant. Numerical research can significantly complement the results of analytical research, and for many models it is the only feasible option. The class of problems that can be solved by numerical methods is much wider than the class of problems available to analytical methods.

6. Analysis of numerical results and their application. At this final stage, the question arises about the correctness and completeness of the modeling results, the adequacy of the model, the degree of its practical application. Mathematical methods of checking the results can reveal the incorrectness of the model and thus narrow the class of potentially correct models. The analysis of theoretical conclusions and numerical results allows revealing shortcomings of initial statement of the problem constructed by the mathematical model.

Since modern mathematical problems can be complex in structure and have a large dimension, it often happens that the known algorithms and programs for the computer do not allow solving the problem in its original form. If it is impossible to develop new algorithms and programs in a short time, the initial problem statement and model are simplified: the conditions are removed and combined, the number of factors taken into account is reduced, nonlinear relations are replaced by linear ones, and so on.

The disadvantages that cannot be corrected at the intermediate stages of modeling are removed at the further stages. But it means that the cycle matters. After starting the research with simple models, you can quickly use useful data, and then move on to creating a larger rooted model. 


\subsection{New information operators}

Here are examples of problems where the interlineation operators of functions are effectively used.

The problem of reproducing the surface $z=f(x, y)$ of the ocean floor or sea according to the sonar data obtained on different lines - the courses of a ship with a sonar, is a typical problem of function recovery of two variables according to its traces on several lines. Here $x, y$ are the coordinates of a variable point on the surface of the ocean or sea in some coordinate system selected by the researcher; $z=f(x, y)$ is the distance from the surface of the ocean or sea at a point with coordinates $(x, y)$ to the bottom. Traces $\left.\varphi_{k}(x, y)\right|_{\Gamma_{k}}=\left.f(x, y)\right|_{\Gamma_{k}}$ of the function $f(x, y)$ (sonar data) on the lines $\Gamma_{k}(k=\overline{1, M}), M(M \geq 2)$ (the courses of the ship) are used for buildings.

According to the abovementioned lines and functions $\varphi_{k}(x, y)$ (or their values at some points of the lines $\Gamma_{k}$ ), one builds the function $f(x, y)$ on the basis of one of the formulas of piecewise polynomial interlineation. These formulas are easy to program. Therefore, the building of the function $f(x, y)$ and its level lines can be entrusted to the on-board computer. The course of the ship is determined by the researcher. It should be noted that traces $\varphi_{k}(x, y)$ are functions of one variable: $\varphi_{k}(x, y)=\varphi_{k}^{*}(x) \quad$ or $\quad \varphi_{k}(x, y)=\varphi_{k}^{*}(y)$, or $\varphi_{k}(x, y)=\varphi_{k}(x(t), y(t))=\varphi_{k}^{*}(t)$.

Another example of effective use of interlineation is the approximate reproduction of the surface of a space body according to radar. The task of restoring the surface of a cosmic body according to radar arises not only in astronomy. Its effective solution can also affect the development of defense technologies and others. Let the radar beam travel along some preselected system of lines $\Gamma_{k}, k=\overline{1, M}$ on the space object being studied (or simply on a sufficiently distant object). The beam is reflected from the object, which makes it possible to obtain the distance to the point of reflection: the value of the function $z=f(x, y)$ in the coordinate system $x, y, z$ selected accordingly. Here $z$ is the distance from the point with coordinates $(x, y)$ on the object to the radar (on the specified lines-courses of the locator beam). Processing of such information often has to happen quickly enough and requires the mathematical device which uses the received data in the most natural way. This possibility is provided by the interlineation.

As for the interflatation operators, they can be used in the design of hulls of aircraft, ships and cars; when approximating the functions of three variables using projections or tomograms coming from a computer tomography; with non-destructive testing of threedimensional objects (for example, at customs), etc. The interstripation operators can be used in practice when processing data obtained from a satellite moving over the surface under study on different trajectories (orbits) at a fairly high altitude. These data provide information about the surface under study (for example, photographs of the surface along the orbit) not on the lines, but on the bands along these lines. The task is to restore (perhaps approximate) the relief of the surface between the strips with the help of known reliefs on the strips. Thus, the problem that arises here can be formulated as follows. A system of bands on the surface and a system of traces of the function of two variables (relief of this surface) on these bands are given. It is necessary to restore (possibly approximately) this function in points between strips.

Definition 1. The interlineation of a function $f(x, y)$ on several lines $\Gamma_{k}, k=1,2, \ldots, K$ will be called the restoration of the function $f(x, y)$ on its traces $\phi_{k} f(x, y)=f(x, y)$ on the 
lines $\Gamma_{k}$. That is, solving the problem of interlineation on given tracks $\phi_{k} f(x, y)$ means building a function of $\mathrm{T}_{K} f(x, y)=f(x, y)$ (we will call it an interlineant), which has a property $\mathrm{T}_{K} f(x, y)=\phi_{k} f(x, y)$ on lines $\Gamma_{k}$.

Definition 2. Under the traces of a function $g(x, y)$ on the lines $x_{k}=k \Delta-\Delta / 2$, $y_{j}=j \Delta-\Delta / 2, k, j=\overline{1, \ell}, \Delta=1 / \ell$, we understand, respectively, the function of one variable $g\left(x_{k}, y\right), 0 \leq y \leq 1, g\left(x, y_{j}\right), 0 \leq x \leq 1$ (see Fig.1).
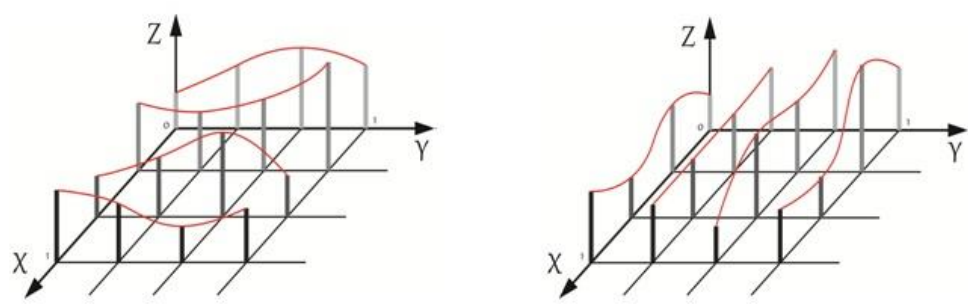

Figure1. Traces of a function $g(x, y)$

\section{RESEARCH RESULTS}

The elements of the theory of new information operators are taught at the Ukrainian Engineering Pedagogics Academy for Master's degree students in the courses "Theoretical, Physical and Information Bases of Industry Knowledge", "Mathematical Methods of Process Description", "Innovative Technologies and Resource Management in the Industry", "Numerical Modeling Technologies". These courses are provided with manuals and guidelines, which detail the basics of this theory. The Master's degree students acquire practical skills in building interlineation operators. As part of the course "Information Technology in Research", which is taught to PhD students, students get acquainted with the operators of interlineation, as well as operators of interflatation, interstripation and others in more detail. During their training, the future doctors of philosophy acquire skills in building mathematical models of the research, learn how to select effective methods of experimental data processing, and plan new experiments taking into account the type of the research task.

One of the most important and most frequently seen problems in mathematical modeling is the problem of numerical integration [21] (methods of approximate calculation of integrals from fast-oscillating functions differ from the usual ones [4], [22] - [24]). Many studies have been devoted to the issue of numerical integration of functions of several variables. The most well-known methods used by modern engineers include the method of central rectangles, the method of trapezoids, Simpson's formula and Gauss's formula. If we classify these studies in the multidimensional case by the type of information assignment, then mainly when building cubature formulas for the approximate calculation of double integrals, the information about the function is given by the values in points.

In this section, the cubature formulas of the approximate calculation of double integrals for different information operators are given. The cubature formulas are given in the case when the information about the subintegral function is given by traces on lines and in points. In addition, the algorithm for the optimal choice of lines in the construction of the cubature formula for the approximate calculation of double integrals from the function of two variables is indicated. The results of these studies are based on the theory of approximate calculation of 
integrals from rapidly oscillating functions of many variables using new information operators [4], [25] - [29]. However, these results alone are also of great value, as numerical integration is often used in mathematical modeling of processes.

\subsection{The calculation of double integrals in the case when the information about the subintegral function is given on the lines}

To calculate the integral

$$
I_{1}^{2}=\int_{0}^{1} \int_{0}^{1} f(x, y) d x d y
$$

the formula is offered

$$
\begin{aligned}
& \Phi_{1}^{2}=\int_{0}^{1} \int_{0}^{1} J f(x, y) d x d y \\
& J f(x, y)=\sum_{k=1}^{\ell} f\left(x_{k}, y\right) h_{0 k}(x)+\sum_{j=1}^{\ell} f\left(x, y_{j}\right) H_{0 j}(y)-\sum_{k=1}^{\ell} \sum_{j=1}^{\ell} f\left(x_{k}, y_{j}\right) h_{0 k}(x) H_{0 j}(y) \\
& h_{0 k}(x)=\left\{\begin{array}{l}
1, x \in X_{k}, \\
0, x \notin X_{k},
\end{array} \quad k=\overline{1, \ell}, \quad H_{0 j}(y)=\left\{\begin{array}{l}
1, y \in Y_{j}, \\
0, y \notin Y_{j},
\end{array} \quad j=\overline{1, \ell},\right.\right. \\
& X_{k}=\left[x_{k-1 / 2}, x_{k+1 / 2}\right], Y_{j}=\left[y_{j-1 / 2}, y_{j+1 / 2}\right] \text {, } \\
& x_{k}=k \Delta-\Delta / 2, \quad y_{j}=j \Delta-\Delta / 2, k, j=\overline{1, \ell}, \Delta=1 / \ell .
\end{aligned}
$$

If we substitute the expression for the operator of interlineation $J f(x, y)$, we obtain an explicit form of the corresponding cubature formula:

$$
\Phi_{1}^{2}=\sum_{k=1}^{\ell} \int_{x_{k-\frac{1}{2}}}^{x_{k+\frac{1}{2}}} d x \int_{0}^{1} f\left(x_{k}, y\right) d y+\sum_{j=1}^{\ell} \int_{0}^{1} f\left(x, y_{j}\right) d x \int_{y_{j-\frac{1}{2}}}^{y_{j+\frac{1}{2}}} d y-\sum_{k=1}^{\ell} \sum_{j=1}^{\ell} f\left(x_{k}, y_{j}\right)_{x_{k-\frac{1}{2}}}^{x_{k+\frac{1}{2}}} d x \int_{y_{j-\frac{1}{2}}}^{y_{j+\frac{1}{2}}} d y .
$$

The proposed cubic formula has a different approximation error depending on the class of functions which the subintegral function belongs to. We give an estimate of the error of the approximate calculation of the integral in the case when the class $H_{1}^{2,1}(M, M)$ is considered. $H_{1}^{2,1}(M, M)$ is a class of real functions defined on $G=[0,1]^{2}$ and such that partial derivatives are bounded:

$$
\left|f^{(1,0)}(x, y)\right| \leq M, \quad\left|f^{(0,1)}(x, y)\right| \leq M, \quad\left|f^{(1,1)}(x, y)\right| \leq M .
$$

Theorem 1. [12] Suppose that $f(x, y) \in H_{1}^{2, r}(M, M)$ and the function is given by $N=2 \ell$ traces on a system of mutually perpendicular lines $f\left(x_{k}, y\right), k=\overline{1, \ell}$, $f\left(x, y_{j}\right), j=\overline{1, \ell}$ in the domain $G=[0,1]^{2}$. The following estimate is valid for the cubature formula:

$$
\rho\left(I_{1}^{2}, \Phi_{1}^{2}\right)=\left|\int_{0}^{1} \int_{0}^{1}(f(x, y)-J f(x, y)) d x d y\right| \leq \frac{M}{16 \ell^{2}}=\frac{M}{4 N^{2}} .
$$

Here are the results of testing the presented cubature formula in the system of computer mathematics MathCad (see Tab. 1, Fig. 2). 
Example 1. Let the function be given by traces $f\left(x_{k}, y\right), k=\overline{1, \ell}, f\left(x, y_{j}\right), j=\overline{1, \ell}$ on a system of mutually perpendicular lines $x_{k}=k \Delta-\frac{\Delta}{2}, y_{j}=j \Delta-\frac{\Delta}{2}, k, j=\overline{1, \ell}, \Delta=\frac{1}{\ell}$ in the domain $G=[0,1]^{2}$.

To calculate $I_{1}^{2}$ let us consider the cubature formula $\Phi_{1}^{2}$. In the class $H_{1}^{2,1}(M, M)$ for the function $f(x, y)=\frac{1}{2}(\cos (2 x-2 y)-\cos (2 x+2 y))$ the following numerical results of the approximate calculation by the cubature formula $\Phi_{1}^{2}$ are valid.

Table 1.

Calculation of $I_{1}^{2}$ using the cubature formula $\Phi_{1}^{2}$

\begin{tabular}{|c|c|c|c|c|}
\hline$\ell$ & $\Phi_{1}^{2}$ & $I_{1}^{2}$ & $E=\left|I_{1}^{2}-\Phi_{1}^{2}\right|$ & $\varepsilon=1 / 16 \ell^{2}$ \\
\hline 4 & 0.501312762205496 & 0.50136796566562 & 0.000055203460124 & 0.00391 \\
\hline 6 & 0.501357149641647 & 0.50136796566562 & 0.000010816023973 & 0.00174 \\
\hline 10 & 0.501366569721889 & 0.50136796566562 & 0.00000139594373 & 0.00063 \\
\hline 15 & 0.501367690281103 & 0.50136796566562 & 0.000000275384517 & 0.00028 \\
\hline 20 & 0.501367878571774 & 0.50136796566562 & 0.000000087093845 & 0.00016 \\
\hline 25 & 0.501367929999473 & 0.50136796566562 & 0.000000035666147 & 0.0001 \\
\hline
\end{tabular}

$$
\begin{aligned}
& 0 \leq x \leq L \quad 0 \leq y \leq L \quad L:=1 \quad M:=4 \quad f(x, y):=\frac{1}{2} \cdot(\cos (2 x-2 y)-\cos (2 \cdot x+2 \cdot y)) \\
& \mathrm{h}:=\frac{\mathrm{L}}{\mathrm{M}} \quad \mathrm{h}=0.25 \quad \mathrm{p}:=1 \ldots \mathrm{M} \quad \mathrm{s}:=1 \ldots \mathrm{M} \quad \mathrm{x}_{\mathrm{p}}:=\mathrm{p} \cdot \mathrm{h}-\frac{\mathrm{h}}{2} \quad \mathrm{y}_{\mathrm{s}}:=\mathrm{s} \cdot \mathrm{h}-\frac{\mathrm{h}}{2} \\
& \operatorname{Ilin}:=\sum_{p=1}^{M}\left[\int_{0}^{1} f\left(x_{p}, y\right) \cdot \int_{(p-1) \cdot h}^{p \cdot h} 1 d x \cdot 1 d y\right] \quad \operatorname{Lin}:=\sum_{s=1}^{M}\left[\int_{0}^{1} f\left(x, y_{s}\right) \cdot \int_{(s-1) \cdot h}^{s \cdot h} 1 d y \cdot 1 d x\right] \\
& \text { I3 }:=\sum_{s=1}^{M} \sum_{p=1}^{M}\left[f\left(x_{p}, y_{s}\right) \cdot \int_{(p-1) \cdot h}^{p \cdot h} 1 d x \cdot \int_{(s-1) \cdot h}^{s \cdot h} 1 d y\right] \quad \text { It }:=\int_{0}^{L} \int_{0}^{L} f(x, y) d x d y \\
& \text { Iint }:=\mathrm{I} \text { lin }+\mathrm{I} \text { 2in }-\mathrm{I} 3 \quad \text { Iint }=0.501312762205496 \\
& \text { It }=0.50136796566562 \quad \mid \text { Iint }- \text { It } \mid=0.000055203460124
\end{aligned}
$$

Figure2. Calculation of $I_{1}^{2}$ using the cubature formula $\Phi_{1}^{2}$ in MathCad

\subsection{The optimal selection of lines when calculating double integrals.}

The algorithm for optimal line selection will be demonstrated for an approximate calculation of the integral of the form

The cubature formula

$$
I_{2}(f)=\int_{-1}^{1} \int_{-1}^{1} f\left(x_{1}, x_{2}\right) d x_{1} d x_{2} .
$$

$$
\tilde{I}_{2}(f)=\int_{-1}^{1} \int_{-1}^{1} L f\left(x_{1}, x_{2}\right) d x_{1} d x_{2}
$$

is offered for calculation where 


$$
\begin{aligned}
L f\left(x_{1}, x_{2}\right) & =\sum_{i_{1}=1}^{p_{1}} f\left(x_{1 i_{1}}, x_{2}\right) l_{1 p_{1} i_{1}}\left(x_{1}\right)+\sum_{i_{2}=1}^{p_{2}} f\left(x_{1}, x_{2 i_{2}}\right) l_{2 p_{2} i_{2}}\left(x_{2}\right)- \\
& -\sum_{i_{1}=1 i_{2}=1}^{p_{1}} \sum_{2}^{p_{2}} f\left(x_{1 i_{1}}, x_{2 i_{2}}\right) l_{1 p_{1} i_{1}}\left(x_{1}\right) l_{2 p_{2} i_{2}}\left(x_{2}\right),
\end{aligned}
$$

$l_{k p_{k} i_{k}}$ - is the basic Lagrange polynomials, $l_{k p_{k} i_{k}}\left(x_{k_{i}^{\prime}}\right)=\delta_{i_{k} i_{k}^{\prime}}, \quad k=1,2, x_{1 i_{1}}=\cos \left(i_{1} \pi /\left(p_{1}+1\right)\right)$, $i_{1}=\overline{1, p_{1}}, \quad x_{2 i_{2}}=\cos \left(i_{2} \pi /\left(p_{2}+1\right)\right), \quad i_{2}=\overline{1, p_{2}}-$ are zeros of the Chebyshev polynomials $U_{p_{1}}, U_{p_{2}}$ of the $2^{\text {nd }}$ kind respectively for degree $p_{1}$ and $p_{2}$

$$
U_{m}(t)=\frac{\sin (m+1) \theta}{\sin \theta}, \quad \cos \theta=t, \quad m=0,1, \ldots
$$

The cubature formula has the following expanded form:

$$
\begin{gathered}
\tilde{I}_{2}(f)=\sum_{i_{1}=1}^{p_{1}} \int_{-1}^{1} l_{1 p_{1} i_{1}}\left(x_{1}\right) d x_{1} \int_{-1}^{1} f\left(x_{1 i_{1}}, x_{2}\right) d x_{2}+\sum_{i_{2}=1}^{p_{2}} \int_{-1}^{1} l_{2 p_{2} i_{2}}\left(x_{2}\right) d x_{2} \int_{-1}^{1} f\left(x_{1}, x_{2 i_{2}}\right) d x_{1}- \\
-\sum_{i_{1}=1 i_{2}=1}^{p_{1}} f\left(x_{1 i_{1}}, x_{2 i_{2}}\right) \int_{-1}^{1} l_{1 p_{1} i_{1}}\left(x_{1}\right) d x_{1} \int_{-1}^{1} l_{2 p_{2} i_{2}}\left(x_{2}\right) d x_{2} .
\end{gathered}
$$

In [30] the estimation of error of calculating an integral by the cubature formula on a class of differentiated functions is presented

$$
\left|I_{2}(f)-\tilde{I}_{2}(f)\right| \leq \frac{M p_{1} p_{2} \pi^{2}}{2^{p_{1}+p_{2}}\left(p_{1}+1\right) !\left(p_{2}+1\right) !} .
$$

Let us show an example which will ensure that at very small quantity of lines it is possible to reach very high accuracy in calculations. Indeed, this algorithm can be used only for those mathematical models where the experimental data are obtained in the nodes of the Chebyshev polynomials of the $2^{\text {nd }}$ kind.

Here are the results of testing the presented cubature formula in the system of computer mathematics MathCad (see Tab. 2, Fig. 3).

Example 2. For the function $f\left(x_{1}, x_{2}\right)=\cos \left(x_{1}+x_{2}\right),\left|f^{\left(p_{1}, p_{2}\right)}\left(x_{1}, x_{2}\right)\right| \leq 1$ the results of calculations are given in the table.

Table 2.

Calculation of $I_{2}$ using the cubature formula $\tilde{I}_{2}$.

\begin{tabular}{|c|c|c|c|}
\hline$p_{1}=p_{2}=\ell$ & $I_{2}(f)$ & $\tilde{I}_{2}(f)$ & $\left|I_{2}(f)-\tilde{I}_{2}(f)\right|$ \\
\hline 2 & 2.83229367309428 & 2.82707748909675 & 0.005216183997534 \\
\hline 3 & 2.83229367309428 & 2.83228683047443 & 0.000006842619856 \\
\hline 4 & 2.83229367309428 & 2.83229271424136 & 0.000000958852927 \\
\hline 5 & 2.83229367309428 & 2.83229367288868 & 0.000000000205606 \\
\hline 6 & 2.83229367309428 & 2.83229367305887 & 0.000000000035412 \\
\hline
\end{tabular}

3.3. Calculation of double integrals in the case when the information about the subintegral function is given in points

Let $m_{1}=m_{2}=\ell^{2}, N=\ell^{4}$ and

$$
X_{k}=\left[x_{k-1 / 2}, x_{\kappa+1.2}\right], Y_{j}=\left[y_{j-1 / 2}, y_{j+1 / 2}\right], \tilde{X}_{\tilde{k}}=\left[\tilde{x}_{\tilde{k}-1 / 2}, \tilde{x}_{\tilde{k}+1 / 2}\right], \tilde{Y}_{\tilde{j}}=\left[\tilde{y}_{\tilde{j}-1 / 2}, \tilde{y}_{\tilde{j}+1 / 2}\right] \text {, }
$$




$$
\begin{gathered}
h_{0 k}(x)=\left\{\begin{array}{l}
1, x \in X_{k}, \quad k=\overline{1, \ell}, \quad H_{0 j}(y)=\left\{\begin{array}{l}
1, y \in Y_{j}, \\
0, y \notin Y_{j},
\end{array} \quad j=\overline{1, \ell},\right. \\
\tilde{h}_{0 \tilde{k}}(x)=\left\{\begin{array}{l}
1, x \in \tilde{X}_{\tilde{k}}, \\
0, x \notin \tilde{X}_{\tilde{k}},
\end{array} \quad \tilde{k}=\overline{1, \ell^{2}}, \quad \tilde{H}_{0 \tilde{j}}(y)=\left\{\begin{array}{l}
1, y \in \tilde{Y}_{\tilde{j}}, \\
0, y \notin \tilde{Y}_{\tilde{j}},
\end{array} \tilde{j}=\overline{1, \ell^{2}},\right.\right.
\end{array}\right. \\
x_{k}=k \Delta-\frac{\Delta}{2}, \quad y_{j}=j \Delta-\frac{\Delta}{2}, \quad k, j=\overline{1, \ell,} \quad \Delta=\frac{1}{\ell}, \\
\tilde{x}_{\tilde{k}}=\tilde{k} \Delta_{1}-\frac{\Delta_{1}}{2}, \tilde{y}_{\tilde{j}}=\tilde{j} \Delta_{1}-\frac{\Delta_{1}}{2}, \tilde{k}, \tilde{j}=\overline{1, \ell^{2}}, \quad \Delta_{1}=\frac{1}{\ell^{2}} .
\end{gathered}
$$

Consider an interpolant operator that is built using a spline-interlineant $J f(x, y)$ :

$$
\begin{gathered}
\tilde{J} f(x, y)=\sum_{k=1}^{\ell} \sum_{\tilde{j}=1}^{\ell^{2}} f\left(x_{k}, \tilde{y}_{\tilde{j}}\right) h_{0 k}(x) \tilde{H}_{0 \tilde{j}}(y)+\sum_{j=1}^{\ell} \sum_{\tilde{k}=1}^{\ell^{2}} f\left(\tilde{x}_{\tilde{k}}, y_{j}\right) \tilde{h}_{0 \tilde{k}}(x) H_{0 j}(y)- \\
-\sum_{k=1}^{\ell} \sum_{j=1}^{\ell} f\left(x_{k}, y_{j}\right) h_{0 k}(x) H_{0 j}(y) .
\end{gathered}
$$

To calculate the integral $I_{1}^{2}$ the next formula is proposed:

$$
\begin{gathered}
\Phi_{1}^{2}=\int_{0}^{1} \int_{0}^{1} \tilde{J} f(x, y) d x d y=\sum_{k=1}^{\ell} \sum_{\tilde{j}=1}^{\ell^{2}} f\left(x_{k}, \tilde{y}_{\tilde{j}}\right) \int_{x_{k-\frac{1}{2}}}^{x_{k+\frac{1}{2}}} d x \int_{\tilde{y}_{\tilde{j}-\frac{1}{2}}}^{\tilde{y}_{\tilde{j}+\frac{1}{2}}} d y+ \\
+\sum_{j=1}^{\ell} \sum_{\tilde{k}=1}^{\ell^{2}} f\left(\tilde{x}_{\tilde{k}}, y_{j}\right) \int_{\tilde{x}_{\tilde{k}-\frac{1}{2}}}^{\tilde{x}_{\tilde{k}+\frac{1}{2}}} d x \int_{y_{j-\frac{1}{2}}}^{y_{j+\frac{1}{2}}} d y-\sum_{k=1}^{\ell} \sum_{j=1}^{\ell} f\left(x_{k}, y_{j}\right) \int_{x_{k-\frac{1}{2}}^{2}}^{y_{j+\frac{1}{2}}} d x \int_{y_{j-\frac{1}{2}}}^{\ell} d y, \\
x_{k}=k \Delta-\frac{\Delta}{2}, y_{j}=j \Delta-\frac{\Delta}{2}, \quad k, j=\overline{1, \ell,} \quad \Delta=\frac{1}{\ell}, \\
\tilde{x}_{\tilde{k}}=\tilde{k} \Delta_{1}-\frac{\Delta_{1}}{2}, \tilde{y}_{\tilde{j}}=\tilde{j} \Delta_{1}-\frac{\Delta_{1}}{2}, \tilde{k}, \tilde{j}=\overline{1, \ell^{2}}, \quad \Delta_{1}=\frac{1}{\ell^{2}} .
\end{gathered}
$$

Figure 3 presents the general principle of constructing a grid of nodes, which is used in the cubature formulas with interlineation operators.

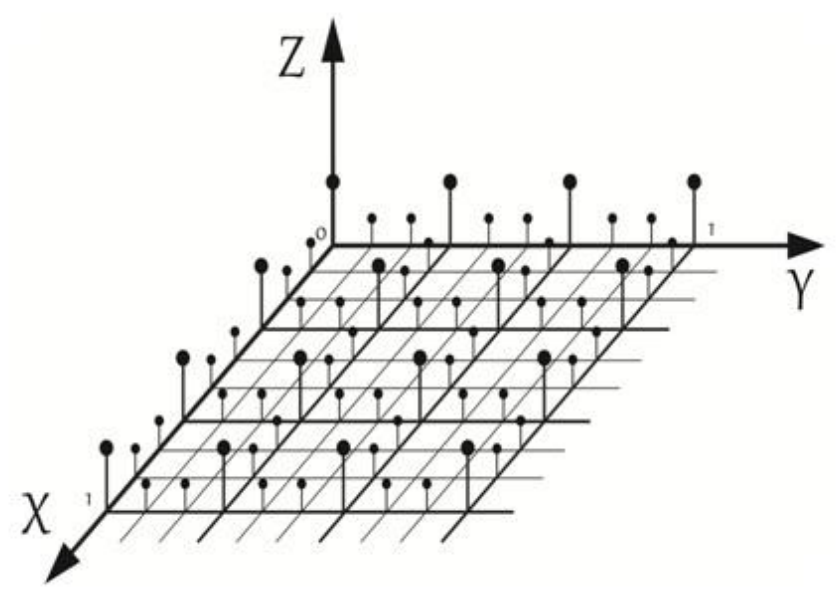

Figure 3. General view of the grid of nodes for the cubature formulas using interlineation operators 
Theorem 2. [12] Let $f(x, y) \in H_{1}^{2,1}(M, M)$ and values $f_{k j}=f\left(x_{k}, y_{j}\right)$, $k=\overline{1, m_{1}}, j=\overline{1, m_{2}}$ given no more than in $N=m_{1} m_{2}, m_{1}=m_{2}=\ell^{2}, N=\ell^{4}$ fixed nodes $\left(x_{k}, y_{j}\right) \in G$. For the cubature formula $\Phi_{1}^{2}(m, n)$ the following estimate of approximation is valid: $\rho\left(I_{1}^{2}, \Phi_{1}^{2}\right) \leq \frac{M+8 M}{16} \frac{1}{\ell^{2}}=\frac{M+8 M}{16} \frac{1}{\sqrt{N}}$. To achieve the error $O\left(\frac{1}{\sqrt{N}}\right)$ the cubature formula $\Phi_{1}^{2}(m, n)$ does not use the values $O\left(\ell^{4}\right)=O(N)$ of the function as a classical, but $O\left(\ell^{3}\right)=O\left(N^{\frac{3}{4}}\right)$.

The given test results are presented in the computer mathematics program MathCad (see Tab. 3, Tab. 4 , Fig. 4).

Example 3. For a function $f(x, y)=\sin (x+y)$ (for which $\tilde{M}=1, \quad M=1$ ) we show that:

$$
\left|I_{1}^{2}-\tilde{\Phi}_{1}^{2}\right| \leq \frac{M}{16} \frac{1}{\ell^{2}}+\frac{M}{2} \frac{1}{\ell^{2}}=\left(\frac{\square}{16}+\frac{M}{2}\right) \frac{1}{\ell^{2}}=\frac{9}{16} \frac{1}{\ell^{2}}=\varepsilon ;
$$

Exact value of integral is $I_{1}^{2}=0.773644542790111$.

Table 3.

Calculation of $I_{2}$ using the cubature formula $\tilde{\Phi}_{1}^{2}$.

\begin{tabular}{|c|c|c|c|}
\hline$\ell$ & $\tilde{\Phi}_{1}^{2}$ & $\left|I_{1}^{2}-\tilde{\Phi}_{1}^{2}\right|$ & $\varepsilon$ \\
\hline 10 & 0.773650858142159 & 0.000006315352048 & 0.018 \\
\hline 20 & 0.773644937376223 & 0.000000394586111 & 0.045 \\
\hline 30 & 0.773644620728563 & 0.000000077938452 & 0.002 \\
\hline
\end{tabular}

$$
\begin{aligned}
& \mathrm{L}:=1 \quad \text { ORIGIN }:=1 \quad \mathrm{f}(\mathrm{x}, \mathrm{y}):=\sin (\mathrm{x}+\mathrm{y}) \quad \mathrm{M}:=10 \quad \mathrm{~N}:=\mathrm{M}^{2} \quad \mathrm{~h}:=\frac{\mathrm{L}}{\mathrm{M}} \quad \mathrm{h} 1:=\frac{\mathrm{L}}{\mathrm{N}} \\
& p:=1 . . M \quad s:=1 \ldots M \quad i:=1 . . N \quad j:=1 \ldots N \\
& x_{p}=p \cdot h-\frac{h}{2} \quad x_{i}:=i \cdot h 1-\frac{h 1}{2} \quad y_{s}:=s \cdot h-\frac{h}{2} \quad y_{j}:=j \cdot h 1-\frac{h 1}{2} \\
& \text { I1 }:=\sum_{j=1}^{N} \sum_{p=1}^{M}\left[f\left(x_{p}, y y_{j}\right) \int_{(p-1) \cdot h}^{p \cdot h} 1 d x \cdot \int_{(j-1) \cdot h 1}^{j \cdot h l} 1 d y\right] \\
& \text { I2 }:=\sum_{s=1}^{M} \sum_{i=1}^{N}\left[f\left(x_{i}, y_{s}\right) \cdot \int_{(i-1) \cdot h 1}^{i \cdot h 1} 1 d x \cdot \int_{(s-1) \cdot h}^{s \cdot h} 1 d y\right] \\
& \mathrm{I} 3:=\sum_{\mathrm{s}=1}^{\mathrm{M}} \sum_{\mathrm{p}=1}^{\mathrm{M}}\left[\mathrm{f}\left(\mathrm{x}_{\mathrm{p}}, \mathrm{y}_{\mathrm{s}}\right) \cdot \int_{(\mathrm{p}-1) \cdot \mathrm{h}}^{\mathrm{p} \cdot \mathrm{h}} 1 \mathrm{dx} \cdot \int_{(\mathrm{s}-1) \cdot \mathrm{h}}^{\mathrm{s} \cdot \mathrm{h}} 1 \mathrm{dy}\right] \quad \mathrm{I}=\mathrm{I} 1+\mathrm{I} 2-\mathrm{I} 3 \quad \mathrm{I}=0.773650858142159 \\
& \text { It }:=\int_{0}^{L} \int_{0}^{L} f(x, y) d x d y \quad \text { It }=0.773644542790111 \quad \mid \text { It }- \text { I } \mid=0.000006315352048 \\
& \mathrm{IZ}:=\sum_{\mathrm{j}=1}^{N} \sum_{\mathrm{i}=1}^{\mathrm{N}}\left[\mathrm{f}\left(\mathrm{xx}_{\mathrm{i}}, \mathrm{yy} \mathrm{y}_{\mathrm{j}}\right) \cdot \int_{(\mathrm{i}-1) \cdot \mathrm{h} 1}^{\mathrm{i} \cdot \mathrm{h} 1} 1 \mathrm{dx} \cdot \int_{(\mathrm{j}-1) \cdot \mathrm{h} 1}^{\mathrm{j} \cdot \mathrm{h} 1} 1 \mathrm{dy}\right] \quad \begin{array}{c}
\mathrm{IZ}=0.773650989860203 \\
|\mathrm{It}-\mathrm{IZ}|=0.000006447070092
\end{array}
\end{aligned}
$$

Figure 4. Calculation of ${ }_{2}$ using the cubature formula $\tilde{I}_{2}$ in MathCad 

the formula

Example 4. The purpose of the numerical experiment is to compare the formula $\Phi_{1}^{2}$ with

$$
\Phi_{1}^{2}=\sum_{k=1}^{\ell^{2}} \sum_{j=1}^{\ell^{2}} f\left(x_{k}, y_{j}\right) \int_{x_{k-\frac{1}{2}}}^{x_{k+\frac{1}{2}}} d x \int_{y_{j-\frac{1}{2}}}^{y_{j+\frac{1}{2}}} d y
$$

by parameters such as the number of values $Q, Q$ of function $f(x, y)$ and accuracy $\varepsilon_{1}, \varepsilon_{2}$.

The table 4 shows that at the same value of accuracy the cubature formula $\Phi_{1}^{2}$ uses less nodes of function than the cubature formula $\Phi_{1}^{2}$.

Table 4.

Calculation of $I_{1}^{2}$ using the cubature formula $\Phi_{1}^{2}$ and $\Phi_{1}^{2}$

\begin{tabular}{|l|c|c|c|c|}
\hline$\ell$ & $\varepsilon_{1}$ & $Q=2 \ell^{3}-\ell^{2}$ & $\varepsilon_{2}$ & $Q=\ell^{4}$ \\
\hline 10 & $6.31 \cdot 10^{-6}$ & 1900 & $6.44 \cdot 10^{-6}$ & 10000 \\
\hline 20 & $3.94 \cdot 10^{-7}$ & 15600 & $4.02 \cdot 10^{-7}$ & 160000 \\
\hline 30 & $7.79 \cdot 10^{-8}$ & 53100 & $7.95 \cdot 10^{-8}$ & 810000 \\
\hline
\end{tabular}

\section{CONCLUSIONS AND PROSPECTS FOR FURTHER RESEARCH}

As a result of scientific and technological progress, mathematical modeling has become an integral part of scientific research in various fields. Information technologies have contributed to the development of mathematical methods and mathematical modeling, expanded the scope of their implementation in both sciences and the humanities. Mathematical modeling is currently one of the main methods in dissertation research, so the issue of modern training of young scientists in this area is relevant.

The analysis of the scientific literature allowed us to find a problem where reviewing the theoretical foundations of new information operators is appropriate. The example of the problem of numerical integration of two variable functions shows a way of building cubature formulas depending on the type of input information about the function. We considered the cubature formulas for the approximate calculation of double integrals based on interlineation in the case when the information about the function is given by its traces on the lines and values of the function at points.

The knowledge monitoring was carried out on the masters and postgraduate students as the result of the implementation of the explanation method which deals with the basics of the theory of new information operators taking the problem of numerical integration of the functions of many variables as an example.

The results of monitoring showed a significant increase in the level of skills of applying new information operators in research, there is an increase in research and subject competence in mathematical modeling in experimental groups of students compared to students in control groups. This indicates the viability of the method and the feasibility of its further use in pedagogical practice.

In the future, it is necessary to consider the theoretical foundations of new information operators in more detail, taking the problem of numerical integration of functions of three variables as an example. 


\section{REFERENCES (TRANSLATED AND TRANSLITERATED)}

[1] I. V. Sergienko, O. M. Lytvyn, "New Information Operators in Mathematical Modeling (A Review)," Cybernetics and Systems Analysis, vol. 54(1), pp. 21-30, 2018, doi: 10.1007/s10559-018-0004-5. (in English).

[2] I. V. Sergienko, O.M. Lytvyn, New Information Operators in Mathematical Modeling. Kyiv, Ukraine: Nauk. Dumka, 2018. (in Ukrainian).

[3] O. Ebenhoh, M. Aalst, N. Saadat, T. Nies, A., Matuszynska, "Building mathematical models of biological systems with modelbase, a Python package for semi-automatic ODE assembly and construction of isotope-specific models," Journal of Open Research Software, 2018. [Online]. Available: https://www.biorxiv.org/content/10.1101/362954v1.full.pdf. Accessed on: July 13, 2020. (in English).

[4] I. V. Sergienko, V. K. Zadiraka, O. M. Lytvyn, O. P. Nechuiviter, Optimal Algorithms of Calculation of Highly Oscillatory Integrals Using New Information Operators, Kyiv, Ukraine: Nauk. Dumka, 2017. (in Ukrainian).

[5] Mathematical Modeling in Research, 2019 [Online]. Available: https://knute.edu.ua/file/MzAxNg==/9bd803c80869ba7ff8bf2b21935bc4c9.pdf. Accessed on: July 13, 2020. (in Ukrainian).

[6] Postgraduate Courses for Mathematical Models in Europe. [Online]. Available: https://www.postgrad.com/courses/mathematical-models/europe/. Accessed on: July 13, 2020. (in English).

[7] Modeling, Control and Information Technologies. [Online]. Available: http://itconfdoc.nuwm.edu.ua/index.php/ITConf/issue/view/4. Accessed on: July 13, 2020. (in Ukrainian).

[8] Mathematical Modeling, Optimization and Information Technology. [Online]. Available: https://www.lap-publishing.com/catalog/details/store/gb/book/978-3-659-71422-1/mathematicalmodeling,-optimization-and-information-technology. Accessed on: July 13, 2020. (in English).

[9] O. M. Lytvyn, O. P. Nechuiviter, "Methods in the Multivariate Digital Signal Processing with Using Spline-interlineation," in Proceeding of IASTED International Conferences on Automation, Control and Information Technology (ASIT 2010), pp. 90-96, 2010. (in English).

[10] O. M. Lytvyn, I. Y. Pershina "The decision of 3d and 4d problems of a computer tomography using interflatation functions," in Proceeding of IASTED International Conferences on Automation, Control and Information Technology (ASIT 2010), pp. 97-102, 2010. (in English).

[11] O. N. Lytvyn, S. Yu. Matveeva, "Aerospace Pictures Processing by Means of Interstripation of Functions of Two Variables," Journal of Automation and Information Science, vol. 45(3), pp. 53-67, 2013. (in English).

[12] O. P. Nechuiviter, H. V. Karhapoltseva, A. G. Kovalchuk, S. O. Chornyi, "Pedagogical aspects of using new informative operators for the problems of numerical integration at the teaching masters of the engineering pedagogics," Problems of Engineering Pedagogic Education. vol. 60, pp. 110-121, 2018, doi: 10.32820/2074-8922-2018-60-110-121. (in Ukrainian).

[13] O. M. Lytvyn, I. I. Pershina, O. O. Lytvyn, O. P. Nechuiviter, Innovative technologies: new informative operators. Kharkiv, UIPA, 2018. (in Ukrainian).

[14] O. M. Lytvyn, I. I. Pershina, O. P. Nechuiviter, Computer mathematics systems in tomography. Kyiv, Ukraine: Nauk. Dumka, 2010. (in Ukrainian).

[15] O. M. Lytvyn, I. I. Pershina, O. P. Nechuiviter, Theoretical, physical and information bases of branch knowledge. Kharkiv, UIPA, 2016. (in Ukrainian).

[16] O. Cherniak, R. Trishch, N. Kim and S. Ratajczak, "Quantitative assessment of working conditions in the workplace," Engineering Management in Production and Services, vol. 12, pp. 99-106, 2020. (in English).

[17] O. Iarmosh, "The applications of integral calculus in socio-economic processes modeling in view of data problems," Socio-economic research bulletin, vol. 1(56). pp. 281-287, 2015 (in Ukrainian).

[18] X. Wang, I. Sloan, "Why are high-dimensional finance problems often of low effective dimension?," SIAM J. Sci. Comput. vol. 27(1). pp. 159-183, 2005.

[19] G. Marion, An Introduction to Mathematical Modelling. [Online]. Available: https://people.maths.bris.ac.uk/ madjl/course_text.pdf. Accessed on: July 13, 2020. (in English).

[20] A. A. Samarskii, A.P. Mikhailov, Principles of Mathematical Modeling Ideas, Methods, Examples. [Online]. Available: http://samarskii.ru/books/book2002.pdf. Accessed on: July 13, 2020. (in English).

[21] V. M. Dubovoy, R. N. Kvetny, O. I. Mikhalev, A. V. Usov, Modeling and optimization of systems: a textbook. Vinnytsia, 2017. (in Ukrainian).

[22] A. Iserles, S. Norsett, "From high oscillation to rapid approximation III: Multivariate expansions," Tech. Reports Numerical Analysis (NA2007/01), DAMPT, University of Cambridge, 2007. (in English). 
[23] G. Milovanovic and M. Stanic, "Numerical Integration of Highly Oscillating Functions," Analytic Number Theory, Approximation Theory and Special Functions, pp. 13-49, 2014. (in English).

[24] J. Gao and A. Iserles, "Error analysis of the extended Filon-type method for highly oscillatory integrals," Tech. Re-ports Numerical Analysis (NA2016/03) DAMPT: University of Cambridge, 2016. (in English).

[25] O. N. Lytvyn, O.P. Nechuiviter, "3D Fourier Coefficients on the Class of Differentiable Functions and Spline Interflatation," Journal of Automation and Information Science, vol. 44(3), pp. 45-56, 2012, doi: 10.1615/JAutomatInfScien.v44.i3.40. (in English).

[26] O. M. Lytvyn, O.P. Nechuiviter, "Approximate Calculation of Triple Integrals of Rapidly Oscillating Functions with the Use of Lagrange Polynomial Interflatation," Cybernetics and Systems Analysis, vol. 50(3), pp. 410-418, 2014, doi: 10.1007/s10559-014-9629-1. (in English).

[27] V. I. Mezhuyev, O.M. Lytvyn, O.P. Nechuiviter, Y.I. Pershyna, O.O. Lytvyn, K.V. Keita, "Cubature formula for approximate calculation of integrals of two-dimensional irregular highly oscillating functions," U.P.B. Sci. Bull., Series A, vol. 80(3), pp. 169-182, 2017. (in English).

[28] O. M. Lytvyn, O. P. Nechuiviter, I. I. Pershyna, V. I. Mezhuyev, "Input Information in the Approximate Calculation of Two-Dimensional Integral from Highly Oscillating Functions (Irregular Case)," in Recent Developments in Data Science and Intelligent Analysis of Information. Proceedings of the XVIII International Conference on Data Science and Intelligent Analysis of Information. Kyiv, pp. 365-373, 2019, doi: 10.1007/978-3-319-97885-7_36. (in English).

[29] O. P. Nechuiviter, "Cubature formula for approximate calculation integral of highly oscillating function of tree variables (irregular case)," Radio Electronics, Computer Science, Control, vol. 4, pp. 65-73, 2020. doi: 10.15588/1607-3274-2020-4-7. (in English).

[30] O. M. Lytvyn, O. P. Nechuiviter, "Approximate calculation of double integrals using Lagrangian polynomial interlineation," Taurian Bulletin of Informatics and Mathematics, vol. 1, pp. 66-72, 2012. (in Ukrainian).

\title{
ЗАСТОСУВАННЯ ТЕОРІЇ НОВИХ ІНФОРМАЦИЙНИХ ОПЕРАТОРІВ ПІД ЧАС ПРОВЕДЕННЯ ДОСЛІДЖЕНЬ У ГАЛУЗІ ІНФОРМАЦЙНИХ ТЕХНОЛОГІЙ
}

\author{
Олеся Петрівна Нечуйвітер \\ доктор фізико-математичних наук, доцент, \\ завідувачка кафедри інформаційних комп'ютерних технологій і математики \\ Українсько інженерно-педагогічна академія, м. Харків, Україна \\ ORCID ID 0000-0003-2775-8471 \\ olesia.nechuiviter@gmail.com
}

\begin{abstract}
Анотація. Завдяки стрімкому розвитку та впровадженню в життя новітніх інформаційних технологій у багатьох галузях науки та техніки відбулися значні зміни. Зокрема з'явились нові математичні теорії, які можуть бути ефективно використані при побудові та вдосконалені існуючих математичних моделей різноманітних явищ та об'єктів. Математичне моделювання на даний час $\epsilon$ одним 3 основних методів у наукових дослідженнях технічних, соціальних, економічних процесів та природних явищ. Без використання математичних методів та алгоритмів не відбувається жодне дисертаційне дослідження. Тому при підготовці докторів філософії необхідно знайомити молодих науковців із сучасними тенденціями розвитку математичного моделювання.

Розвиток інформаційних технологій сприяв виникненню нових підходів до отримання, обробки та аналізу інформації в наукових дослідженнях. Саме так була створена теорія нових інформаційних операторів, яка знайшла широке застосування в математичному моделюванні.

Здійснений аналіз літератури дав змогу акцентувати увагу на необхідності розгляду основ теорії нових інформаційних операторів та їх застосування до чисельного інтегрування функцій декількох змінних. На прикладі задачі чисельного інтегрування функцій двох змінних продемонстровано як побудувати кубатурні формули у випадку, коли вхідна інформація задається слідами функції на лініях та значеннями функції в точках. Запропоновані формули також мають високу точність, але використовують значно менше вхідної інформації в порівнянні 3 класичними формулами чисельного інтегрування
\end{abstract}


подвійних інтегралів. Усі результати підкріплені численними прикладами, зробленими в системі комп'ютерної математики Mathcad.

Упровадження розробленої методики щодо можливості використання нових інформаційних операторів у наукових дослідженнях показало свою ефективність при проведенні семінарів 3 магістрами та аспірантами.

Ключові слова: ІКТ; математичне моделювання в наукових дослідженнях; нові інформаційні оператори; чисельні алгоритми; інтегрування функцій багатьох змінних; Mathcad; підготовка докторів філософії.

\title{
ПРИМЕНЕНИЕ ТЕОРИИ НОВЫХ ИНФОРМАЦИОННЫХ ОПЕРАТОРОВ ПРИ ПРОВЕДЕНИИ ИССЛЕДОВАНИЙ В ОБЛАСТИ ИНФОРМАЦИОННЫХ ТЕХНОЛОГИЙ
}

\author{
Олеся Петровна Нечуйвитер \\ доктор физико-математических наук, доцент, \\ заведующая кафедрой информационных компьютерных технологий и математики \\ Украинская инженерно-педагогическая академия, г. Харьков, Украина \\ ORCID ID 0000-0003-2775-8471 \\ olesia.nechuiviter@gmail.com
}

\begin{abstract}
Аннотация. Благодаря стремительному развитию и внедрению в жизнь новейших информационных технологий во многих отраслях науки и техники произошли значительные изменения. В частности появились новые математические теории, которые могут быть эффективно использованы при построении и усовершенствованные существующих математических моделей различных явлений и объектов. Математическое моделирование в настоящее время является одним из основных методов в научных исследованиях технических, социальных, экономических процессов и природных явлений. Без использования математических методов и алгоритмов не обходится ни одно диссертационное исследование. Именно поэтому при подготовке, в частности, докторов философии актуально ознакомление молодых ученых с современными тенденциями развития математического моделирования.

Развитие информационных технологий способствовало возникновению новых подходов к получению, обработке и анализу информации в научных исследованиях. Именно так была создана теория новых информационных операторов, которая нашла широкое применение в математическом моделировании.

Проведенный анализ литературы позволил акцентировать внимание на необходимости рассмотрения основ теории новых информационных операторов и их применении к численному интегрированию функций нескольких переменных. На примере задачи численного интегрирования функций двух переменных продемонстрировано построение кубатурных формул в случае, когда входная информация задается следами подинтегральной функции на линиях и значениями функции в точках. Предложенные формулы также имеют высокую точность, но используют значительно меньше входной информации по сравнению с классическими формулами численного интегрирования двойных интегралов. Все результаты подкреплены многочисленными примерами, сделанными в системе компьютерной математики Mathcad.

Внедрение разработанной методики относительно возможности использования новых информационных операторов в исследованиях показало свою эффективность во время семинаров с магистрантами и аспирантами.
\end{abstract}

Ключевые слова: ИКТ; математическое моделирование в научных исследованиях; новые информационные операторы; численные алгоритмы; интегрирования функций многих переменных; Mathcad; подготовка докторов философии.

\section{$(\mathrm{CC})$ EY-NC-SA}

This work is licensed under Creative Commons Attribution-NonCommercial-ShareAlike 4.0 International License. 